\title{
CHANGES IN MALE REPRODUCTIVE SYSTEM INDUCED BY TEMPEH ETHANOL EXTRACT ADMINISTERED TO RATS FROM PRENATAL UNTIL WEANING PERIOD OF LIFE
}

\author{
BAGUS KOMANG SATRIYASA ${ }^{1 *}$, NYOMAN BUDIANI NI² ${ }^{2}$ NYOMAN MANGKU KARMAYA $^{3}$ \\ ${ }^{1}$ Department of Pharmacology, Faculty of Medicine Udayana University, Bali, Indonesia. ${ }^{2}$ Polytechnic of Health, Bali, Indonesia. \\ ${ }^{3}$ Department of Anatomy, Faculty of Medicine Udayana University, Bali, Indonesia. Email: bksatriyasa@unud.ac.id
}

Received: 08 December 2017, Revised and Accepted: 19 January 2018

\section{ABSTRACT}

Objective: Sertoli cell and spermatogonia are formed in the prenatal period, and alterations information process could affect the reproduction function in the adolescence and adult period. This study aimed to unveil the effect of tempeh's isoflavone that was given from prenatal to weaning during childhood period toward the amount of Sertoli cell and spermatogonia.

Method: The study design was randomized post-test only control group design with 15 female Wistar experimental mouse in the aged of $12^{\text {th }}-$ $13^{\text {th }}$ weeks was used and divided into three groups, namely, control groups (C) that were given aquadest, intervention Group 1 (I1) and intervention Group 2 (I2) that was given tempeh $0.5 \mathrm{~g} / \mathrm{kg}$ body weight/day ethanol extract that contains $0.52 \mathrm{mg}$ genistein and $5 \mathrm{~g} / \mathrm{kg}$ body weight/day that contains $5.2 \mathrm{mg}$ genistein, respectively. The intervention was given for a week before copulation, during pregnancy and lactation period. The observed parameters were Sertoli cell and spermatogonia of an early-born mouse.

Result: The amount of Sertoli cell and spermatogonia were different between the three groups $(\mathrm{p}<0.05)$. The I2 group has the lowest amount of Sertoli cell and spermatogonia and shows a significant difference from the control group as well as I1 $(p<0.05)$. Tempeh ethanol extract has a direct impact on reducing the amount of Sertoli cell to about $11 \%$ lower than control. It also affected the number of spermatogonia indirectly through its effect toward Sertoli cells.

Conclusion: Intervention of tempeh ethanol extract to female Wistar experimental mouse from prenatal period to weaning child period could disturb the formation of Sertoli cell and spermatogonia of the early-born mouse.

Keywords: Sertoli cell, Spermatogonia, Tempeh ethanol extract.

(C) 2018 The Authors. Published by Innovare Academic Sciences Pvt Ltd. This is an open access article under the CC BY license (http://creativecommons. org/licenses/by/4. 0/) DOI: http://dx.doi.org/10.22159/ajpcr.2018.v11i5.24173

\section{INTRODUCTION}

Fertilization process occurs if spermatozoa could penetrate through defense wall of the ovum. The ability to do fertilization only owned by a few spermatogonia that have very excellent quality. According to the World Health Organization, $10-15 \%$ married couple in the world having an infertility problem. The aberration of spermatozoa is the leading cause in $25 \%$ of fertile couples. The aberration includes anomalies of morphology, motility, and low spermatozoa concentration in seminal fluid [1]. Spermatogonia are a germinal cell that undergoes differentiation process in testis. The formation and differentiation of spermatozoa occurred since the prenatal period when it is very susceptible to experience derangement of formation and differentiation $[1,2]$.

The primordial germinal cell in human moves slowly like an ameba and arrive in primitive gonadal to form gonad indifferent which are identical in men and women during 4- $6^{\text {th }}$ weeks of gestational age. Several genes are involved in this phenomenon, such as Wilms tumor suppressor 1 and steroidogenic factor 1 . Under the influence of sex region Y protein and locus gene y-linked or testis-determining factor, testicular development is promoted [3,4]. Furthermore, testicular development requires anti-mullerian hormone (AMH) which secreted by Sertoli cell and testosterone hormone that secreted by the leydig cell. Estrogen could inhibit differentiation of these cell $[2,3]$.

Sertoli cell plays essential roles in life continuance of spermatozoa cell. In the human body, Sertoli cell was formed in $6^{\text {th }}$ or $7^{\text {th }}$ weeks of gestational age, afterward merge to form a testicular chord, as a planted place of germinal primordial cells. The Sertoli cell will be developed in accordance with the development of fetus seminiferous tubule. During the fetal period of life, the function of the Sertoli cell is to provide nutrition for other germinal cells, differentiation of germinal cells, preventing germinal cell entering meiosis phase. The role of this cell is affected by testosterone hormone that is secreted by fetal leydig cells [5].

There is assumption related to the similarity of mouse development with human development in the aspect of physiology [6]. Mouse sexual embryo differentiation from gonad differentiation become male or female is started on the 13th day of the gestational period, Sertoli cell differentiation occurs at 13th and a half day after copulation process, approximately in the 14th and a half day of gestational age, the fetal leydig cell may begin to appear and develop. On the $15^{\text {th }}$ day of gestational age, leydig cell starts to secrete testosterone hormone, in the $16^{\text {th }}$ day of gestational age, testicular cord become elongated and curved $[7,8]$. Estrogen hormones are essential for the development of sexual characteristics and reproduction, in testicular development and function process could be influenced by estrogen hormone [34]. Endogenic estrogen inhibits testicular development and function in fetal and neonatal life period. Furthermore, estrogen- $\beta$ receptors are consistently found in seminiferous cord controlling gametogenesis process. Meanwhile, Re $\alpha$ may be expressed in leydig cells controlling steroidogenesis process [9]. Estrogen regulates the expression of StAR gene protein and CYP11A1 [10,32].

The period of embryogenesis is very vulnerable to teratogenic process caused by various etiology including exposure to endocrine disrupting compound (EDC). It has potential to cause gene mutation, mitotic 
disruption, alteration integrity of nucleic acid as well as its function, lack of substrate and precursor consist of hormone biosynthesis and the obstacle of the steroidogenic hormone. This kind of matter could disrupt the formation and development of testis [8,29]. Isoflavone has received enormous attention as it has been demonstrated to be effective in many diseases and has another function as one of EDC due to its estrogenic effect $[33,36]$.

It is mediated through its interaction with estrogen receptors, which result in activation of the estrogenic pathway in target cells. Isoflavones consist of daidzein, genistein, and glycitein. Genistein is an isoflavonoid that has been shown to possess many biological activities in the human body [35]. The strongest isolated isoflavone is equol which is a metabolic product of daidzein $[11,12]$. The interaction of isoflavones with $\operatorname{Re} \beta$ receptors is stronger than Re $\alpha$. When estrogen level is low, isoflavones could act as an estrogen agonist. However, when estrogen level is high, isoflavone could act as an antagonist of estrogen [13].

Not only interact with estrogen receptors but isoflavones also could control endogenic estrogen concentration through its ability to form a bond or metabolizes slowly by P450 aromatase enzyme, $5 \alpha$-reductase, $17 \beta$-hydroxysteroid dehydrogenase (17 $\beta$-OHDH), topoisomerase, and tyrosine kinase [14]. Isoflavones could affect sex hormone bioavailability by stimulating synthesis of sex hormone binding globulin (SHBG). Meanwhile, on leydig cells, isoflavones could downregulate expression of P450c17 (17 $\alpha$-hydroxylase)/C17-20 lyase (CYP17A1) [15,30]. Several studies had evaluated the gonadal effect of isoflavones. The intervention of genistein injection at $1 \mathrm{mg} / \mathrm{mouse} /$ day for 5 days on 1 day old mouse, decreased the expression of RE $\alpha$ and $m R N A$ RA [16].

However, Kim and Park revealed that genistein supplementation on the dietary product as much as $0.02 \%$ and $0.1 \%$ from a prenatal period until 21-day postnatal did not affect total weight of child testis [13]. Supplementation of a high dose of isoflavones in female experimental mouse $(150 \mathrm{mg} / \mathrm{kg}$ weight/day) during the periconception period has offspring with damaged tubules seminiferous and undifferentiated spermatogenic cell with unclear histological appearance [17].

Another study is evaluating the effect of oral isoflavone in Wistar experimental mouse at a dose of $200 \mathrm{mg} / \mathrm{kg}$ body weight/day which started from weaning period to sexual maturity found no effect on the number of spermatogonia, while morphological changes in seminiferous tubules were clearly observed [28].

A different result of studies has been reported according to exposure of isoflavones in perinatal period of the experimental mouse (12-day post conception and 21 days postnatal period)

may induce activity proliferation of leydig cell and upregulate expression of $\mathrm{LH}$ receptors, androgen receptors, and estrogen receptors in progenitor leydig cell [18]. Another related finding, male experimental mouse in the age of 50 days, that was given genistein exposure with a dose of $10 \mathrm{mg}$ and $100 \mathrm{mg}$ per day prenatal period until the age of 21 days, show the overstimulated activity of spermatogenic cell [19].

This research was aimed to confirm the effect of isoflavones exposure in early life period which is still inconsistent. Legumes and its product like tempeh contain a significant amount of isoflavone. Tempeh since long ago has been consumed as the primary foodstuff, especially in Asian countries. Furthermore, tempeh has been considered as a functional foodstuff because it contains a higher amount of nutrition and antioxidant than soybean. Thus, this study was aimed to unveil the effect of isoflavone from tempeh on the amount of Sertoli cell and spermatogonia that were given since prenatal period until weaning.

\section{METHODS}

\section{Study animal}

The experimental animal in this study was female Wistar mouse aged of the $15-16^{\text {th }}$ weeks, healthy, and had been giving birth once. 15 mice that fit with those inclusion criteria were included in this study with the average weight 150 g. Six male Wistar experimental mouse in the age of 16-18 weeks was chosen with the average weight $190 \mathrm{~g}$. Those mice were obtained from Pharmacology Laboratory Faculty of Medicine, Udayana University, and all interventions were conducted in the same laboratory.

Plastic boxes with $40 \mathrm{~cm} \times 15 \mathrm{~cm} \times 10 \mathrm{~cm}$ dimension were used as an animal cage. The base of the cage was covered by husk, and the upper part was covered with wire gauze. The cage was cleaned and husk was replaced every 2 days. Feeding box was cleaned and filled every day, and the cage was kept clean and dry with a stable temperature.

The mice were given the opportunity to adapt within a week with $12 \mathrm{~h}$ of bright and $12 \mathrm{~h}$ of dark. Mice are given water if necessary and standard pellets as much as $12-20$ g per day. The sick mice were not used for the study.

\section{Isoflavones extraction from tempeh}

Wilis soybean variety was processed as tempeh by the researcher. Fermentation was conducted for $48 \mathrm{~h}$. Then, the tempeh was extracted using $96 \%$ ethanol as maceration material followed by evaporation and freeze dryer. The procedure yielded $4 \mathrm{~g}$ of evaporation extract for every $100 \mathrm{~g}$ of tempeh. The concentration of genistein was tested using thin layer chromatography-spectrophoto densitometry. Every $1 \mathrm{ml}$ of preparation weights $1 \mathrm{~g}$, containing $1.04 \mathrm{mg}$ genistein, and phenol $70.25 \mathrm{mg}$ per $100 \mathrm{~g}$ gallic acid equivalent. Every $100 \mathrm{~g}$ of wet weight, contain an amount of water as much as $1.5293 \mathrm{~g}$, ash $0.2158 \mathrm{~g}$, protein $1.9387 \mathrm{~g}$, fat $80,4264 \mathrm{~g}$, and carbohydrates $15.8897 \mathrm{~g}$.

\section{Study design}

Randomized post-test only controls group design was selected as the design of this study. The experimental mouse was randomly divided into three groups, namely, control group (C), intervention Group 1 (I1) which received $0.5 \mathrm{~g} / \mathrm{kg}$ body weight/day $(0.08 \mathrm{ml}$ containing $0.52 \mathrm{mg}$ genistein) ethanol extract and intervention Group 2 (I2) received $5 \mathrm{~g} / \mathrm{kg}$ body weight/ day $(0.75 \mathrm{ml}$ containing genistein $5.2 \mathrm{mg}$ ) ethanol extract $5 \mathrm{~g} / \mathrm{kg}$ body weight/day. The control group (C) was treated with only $0.75 \mathrm{ml}$ aquadest. The intervention was conducted using feeding tube every day at $09.00-$ 10.00 AM. The dose was adjusted according to Lofamina et al. (2014). The intervention was conducted for 56-59 days: 7 days before copulation period, 21-23 days in pregnancy period, and 21 days in lactation period.

The copulation was conducted by placing one male experimental mouse with two to three female experimental mice in one cage. Then, the copulation behavior was observed. Mice is stated pregnant when a vaginal plug was found. The pregnant mice have returned to their original cage until weaning period. From each litter of offspring aged 21 days, two mice were selected randomly for the intervention. At the end of the intervention, the mice were euthanized by the cervicaldislocation method. Then, the testicles were obtained by dissected the mice for histopathological examination.

\section{Gonadal tissue preparation}

The testicles were fixated in $10 \%$ formalin liquid, and then the tissue is processed with Meyer hematoxylin and eosin (HE) staining. Slide preparation was conducted in the standardized laboratory of the pathobiology of Veterinary Faculty, Udayana University.

\section{Testicular histological evaluation}

The observation and evaluation of Sertoli cell and spermatogonia were conducted using Olympus CX 21 microscope. The number of the cell was determined by counting in five large visual fields $(\times 40)$. The slides were documented using Canon EOS 60D camera. All of the procedure was conducted in the laboratory of the pathobiology of Veterinary Faculty, Udayana University.

\section{Statistical analysis}

The statistical analyses were conducted by the descriptive method followed by comparative analysis between group using one-way 
ANOVA test and, finally, post hoc test and way analysis. All data have normal distribution $(p>0.05)$ and homogenous variants $(p>0.05)$. Data analyses were conducted using SPSS software version 17.0 with $95 \%$ confident interval $(\mathrm{p}<0.05)$.

\section{RESULT}

\section{General observation}

The total of experimental mouse mother that we observed is 15 , a total of early-born male mice that we observed for each mother is two, with the resulting total of early-born male mice that we observed are 30 mice (10 mice for each group). The average weight of mother mouse was increase after given intervention, in control group the average of weight is $5.2 \mathrm{~g}$, in intervention Group 1 is $5.6 \mathrm{~g}$, and in intervention Group 2 is $6.2 \mathrm{~g}$. The average weight of early-born mice in control group is $6.8 \mathrm{~g}$, in intervention Group 1 is $7.3 \mathrm{~g}$, and in intervention Group 2 is $8.6 \mathrm{~g}$.

\section{Ratio of Sertoli cell and spermatogonia between group}

The amount of Sertoli cell and spermatogonia in every testicle of early-born mice (Table 1). ANOVA test reveals there are significant differences in the average number of Sertoli cell and spermatogonia from each group.

The average of the Sertoli cell as well as spermatogonia excessively in control group. Meanwhile, the fewest are in the I2 group. Every group shows a different average $\mathrm{p}<0.05$ (Table 1 ).

Post hoc test of Sertoli cell show there is no significant difference in the number of the Sertoli cell between C group and I1 group, otherwise, there is a significant difference in the average number of the Sertoli cell between $\mathrm{C}$ group and I2 group, also between I1 group and I2 group (Fig. 1)

Post hoc test of spermatogonia cell show there is no significant difference in the number of spermatogonia cell between $\mathrm{C}$ group and I1 group. Otherwise, there is a significant difference in the average number of the Sertoli cell between C group and I2 group, also between I1 group and I2 grou-p (Fig. 2).

The histologic structure of rat testes in the three intervention groups showed that most spermatogonia were present in group C, then spermatogonia were the least present in the group of I2. (Figs. 3 and 4).

Effect of intervention on the amount of Sertoli cell and spermatogonia

The effect of tempeh ethanol extract treatment on sertoli and spermatogonia cells is directly and indirectly evaluated through path analysis (Fig. 5)

\section{DISCUSSION}

The formation of testis began with the appearance of the Sertoli cell through the process of somatic cell differentiation and continued with proliferation which increased the number of the Sertoli cells. This process could be affected by the level of endogenic estrogen.

Table 1: Sertoli cell and spermatogonia in control Group, I1, and $\mathrm{I} 2$

\begin{tabular}{lllll}
\hline Variable/group & $\mathbf{n}$ & Mean \pm SD & F & p value \\
\hline Sertoli cell & & & & \\
$\quad$ C & 10 & $130.50 \pm 10.700$ & 4.729 & $0.017^{*}$ \\
I1 & 10 & $127.60 \pm 8.099$ & & \\
I2 & 10 & $117.40 \pm 10.967$ & & \\
Spermatogonia & & & & \\
$\quad$ C & 10 & $691.80 \pm 18.122$ & 12.762 & $0.000^{*}$ \\
I1 & 10 & $677.80 \pm 35.755$ & & \\
I2 & 10 & $632.50 \pm 25.527$ & & \\
\hline * & & & &
\end{tabular}

*Significant $P<0.05$
The lowest amount of Sertoli cell in this study is found in I2 group (Table 1). This phenomenon is directly affected by the intervention of tempeh ethanol extract that contains genistein isoflavone. The excessive intervention of tempeh ethanol extract more than $5 \mathrm{~g} / \mathrm{Kg}$ body weight/ day could increase estrogen level. Isoflavone could form a bond with estrogen receptors, therefore, could mimic estrogen characteristic [20]. Furthermore, high level of isoflavones could trigger aromatase enzyme activity which will convert androgen into estrogen and lead to increased level of endogenic estrogen

The consequences of such phenomenon are a diminishing level of testosterone [21]. Genistein extract had been proved to increase the inhibin- $\alpha$ mRNA and downregulate FSH level in cell culture [22]. Since FSH and testosterone act to increase Sertoli cell proliferation, its deficiency could decrease the population of Sertoli cell [23].

The lowest amount of spermatogonia was also found in I2 group (Table 1). These findings are directly affected by the amount of Sertoli cell and indirectly from tempeh ethanol extract intervention. This phenomenon is in accordance with the evidence of intervention of genistein in pregnancy period of day-12 until day-19 could hamper spermatozoa production [24].

The density of Sertoli cell has a considerable impact on a number of spermatogonia. Increased number of the Sertoli cell positively correlated with increasing spermatogenic capacity. There is also a close correlation between germinal cell and signaling of androgen receptors in Sertoli cell [25]. Sertoli cell secretes transforming growth factor $\beta$ (TGF- $\beta$, TGF $\beta 1$, TGF $\beta 2$, and activin A) and retinoic acid (RA) that are needed for germinal cell differentiation and proliferation [26]. The Sertoli cell also

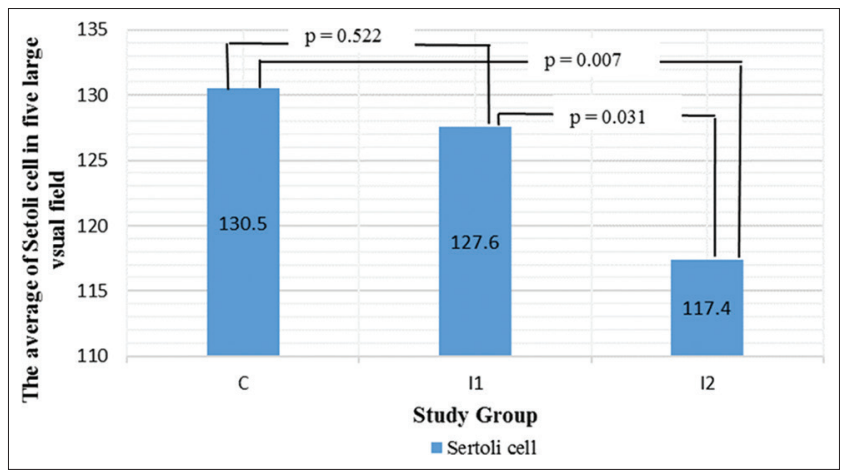

Fig. 1: Post hoc test of Sertoli cell. C group receive $0.75 \mathrm{ml}$ of aquadest; I1 group receive tempeh ethanol extract $0.5 \mathrm{~g} / \mathrm{kg}$ body weight/day; 12 group receive tempeh ethanol extract $5 \mathrm{~g} / \mathrm{kg}$ body weight/day

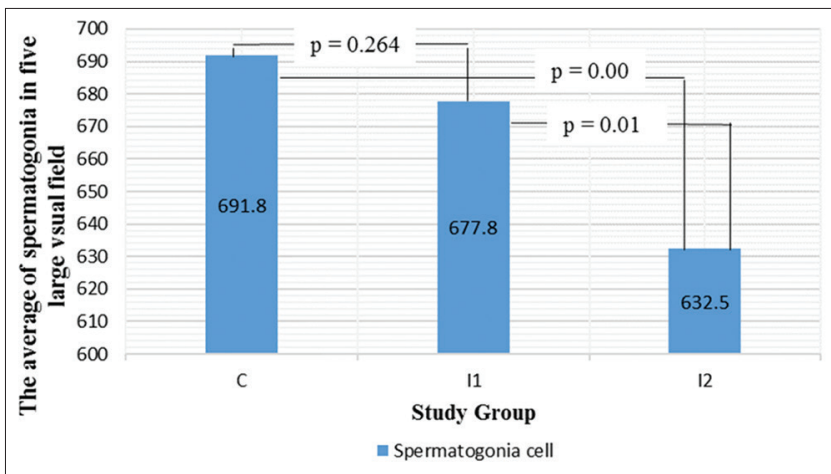

Fig. 2: Post hoc test of spermatogonia cells. C group receive $0.75 \mathrm{ml}$ of aquadest; $\mathrm{I} 1$ group receive tempeh ethanol extract 0.5 $\mathrm{g} / \mathrm{kg}$ body weight/day; I2 group receive tempeh ethanol extract 5 $\mathrm{g} / \mathrm{kg}$ body weight/day 


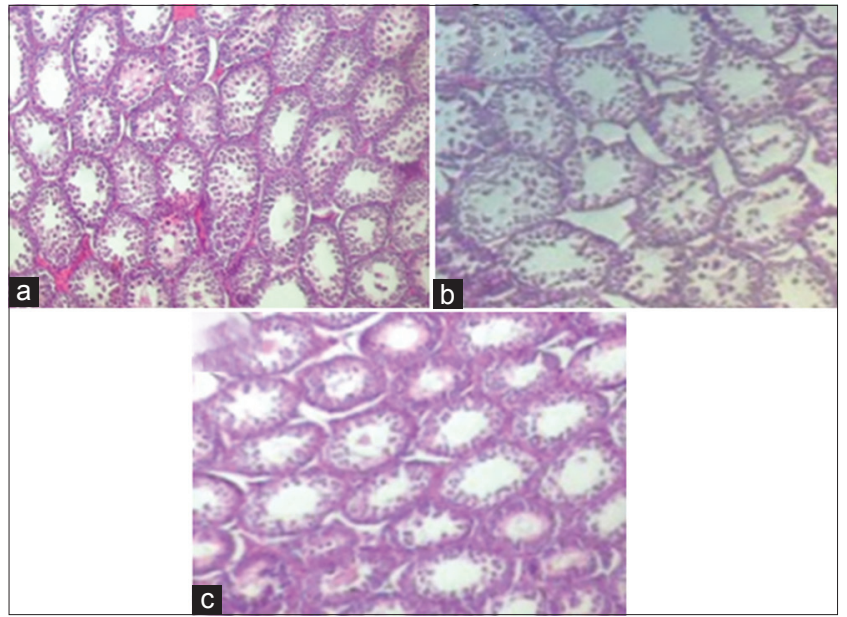

Fig. 3: Histopathology structure of experimental mouse testis in the age of 21 days with $\times 100$ magnification. A, Group $C$ receiving aquadest $0.75 \mathrm{ml}$, show spermatogonia distribution in great quantities and dense population of the seminiferous tubule. B, show histopathology structure of I1 group receiving tempeh ethanol extract $0.5 \mathrm{~g} / \mathrm{kg}$ body weight/day, shows adequate spermatogonia distribution, however, with a loose population of seminiferous tubule and ill-defined border margin. C, shows histopathology structure of I2 group receiving tempeh ethanol extract $5 \mathrm{~g} / \mathrm{kg}$ body weight/day, shows the infrequent distribution of spermatogonia, with sufficient population of seminiferous tubule and unorganized margin border

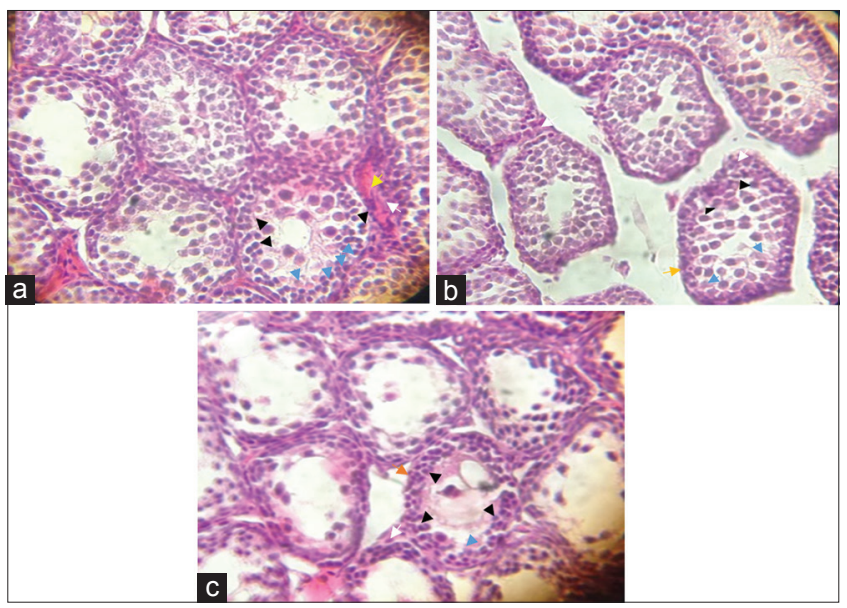

Fig. 4: (a) Histopathology structure of experimental mouse testis in the age of $\mathbf{2 1}$ days with $\times \mathbf{4 0 0}$ magnification. Histopathology structure of testis in $\mathrm{C}$ group receiving $0.75 \mathrm{ml}$ aquadest. It shows great quantities of spermatogonia (black arrow), Sertoli cell lay between spermatogonia (blue arrow), wall margin of seminiferous tubule (yellow arrow), leydig cells (white arrow) and (b) histopathology structure of experimental mouse testis in the age of $\mathbf{2 1}$ days with $\times \mathbf{4 0 0}$ magnification. Histopathology structure of testis in I1 group receiving tempeh ethanol extract $0.5 \mathrm{~g} / \mathrm{kg}$ body weight/day. It shows the excessive distribution of spermatogonia (black arrow). Furthermore, Sertoli cell lay between spermatogonia (blue arrow). Rare seminiferous tubule population with unorganized border margin, (yellow arrow), and leydig cells (white arrow), (c) histopathology structure of experimental mouse testis in the age of 21 days with $\times 400$ magnification. Histopathology structure of testis in I2 group receiving tempeh ethanol extract $5 \mathrm{~g} / \mathrm{kg}$ body weight/day shows the rare distribution of spermatogonia (black arrow), Sertoli cell lay between spermatogonia (blue arrow), wall margin of seminiferous tubule are unorganized (yellow arrow), and leydig cell (white arrow)

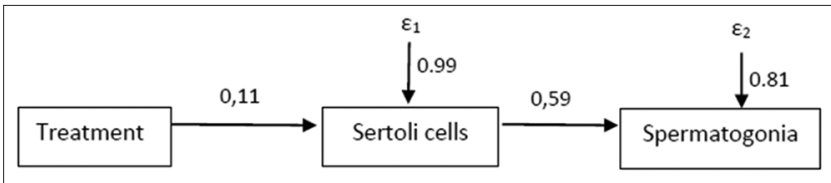

Fig. 5: Effect of intervention on Sertoli cell and spermatogonia. Intervention group receiving tempeh ethanol extract has a direct influence on the amount of Sertoli cell as much as $11 \%$, meanwhile a number of spermatogonia as much as $6 \%$. Direct effect on the Sertoli cell to spermatogonia is $59 \%$. The impact of intervention and total of the Sertoli cell together is $35 \%\left(R^{2}\right.$ 0.353)

maintains and protects the germinal cell, secreting inhibin, $\mathrm{ABP}, \mathrm{AMH} /$ MIS, and prevent germinal cell entering meiosis period. Abnormality in Sertoli cell function could inhibit the development of spermatogenic cell [27].

Another study by Faqi et al. (2004) evaluating the chronic toxicity of isoflavones supplementation $200 \mathrm{mg} / \mathrm{kg}$ body weight/day (low dose isoflavones) and $2000 \mathrm{mg} / \mathrm{kg}$ body weight/day (high dose isoflavones) to male rats reproduction system. There were significant differences in the number of spermatid between low dose isoflavones group (331 \pm 46.7) and high dose isoflavones group (319 \pm 36.4$)$ [37].

Differentiation of germinal cell from gnosis to gonia (spermatogonia) depends on the amount of leydig cell, Sertoli cell, FSH with its cognate receptor, androgen biosynthesis, and $\mathrm{LH}$ with its receptor. The amount of extricated LH is decreasing in the mother that consumed genistein [13]. Isoflavone has a high affinity toward RE $\alpha$ in child's leydig cell which inhibits the activities of the steroidogenic enzyme, for example, StAR, $3 \beta$-HSD, P450 aromatase, and $5 \alpha$-reductase, and thus decreasing the child's testosterone secretion. Furthermore, isoflavone could also stimulate secretion of SHBG resulting in depletion of free plasma testosterone. In the other hand, isoflavone also can bind RE $\beta$ in Sertoli cell which affects proliferation of germinal cells $[14,15]$.

In this study, the difference of the number of Sertoli cell and spermatogonia between $\mathrm{C}$ group and I1 was not statistically significant (p>0.05) (Figs. 1 and 2) although the density of seminiferous tubule in I1 seems loose enough with an irregular surface (Fig. 4b). The possible cause of such phenomena is a disturbance in the seminiferous cord differentiation by prooxidant-oxidant level imbalance which results from the presence of the EDC. Such event could ultimately result in testicular dysfunction [31].

\section{CONCLUSION}

Tempeh ethanol extracts significantly altered the amount of Sertoli cell in seminiferous tubules which subsequently affect the number of spermatogonia. Therefore, the intervention of tempeh ethanol extract per oral to Wistar experimental mouse mother since a week before copulation until weaning period could disturb the formation of Sertoli cell and spermatogonia of the newborn mouse.

\section{CONFLICTS OF INTEREST}

Authors have no conflicts of interest regarding all elements in the study.

\section{REFERENCES}

1. Barbieri RL. Yen and Jaffe's Reproductive Endocrinology: Physiology, Pathophysiology, and Clinical Management. $7^{\text {th }}$ ed. Philadelphia, PA: Elsevier Saunder; 2014. p. 512-37.

2. Fritz MA, Speroff L. Clinical Gynecologic Endocrinology and Infertility. $8^{\text {th }}$ ed. Philadelphia, PA: Lippincott Williams \& Wilkins; 2011. p. 199-42.

3. Sadler TW. Langman's Medical Embryology $12^{\text {th }}$ ed. Jakarta: EGC; 2014. p. 232-59.

4. Sherwood L. Human Physiology from Cells to Systems. $7^{\text {th }}$ ed. Australia: Brooks/Cole Cengage Learning; 2010. p. 741-98. 
5. Huff DS, Ernst LM, Ruchelli ED, Huff DS. Color Atlas of Fetal and Neonatal Histology. USA: Springer; 2011. p. 121-41

6. Iannaccone PM, Jacob HJ. Rats! Dis Model Mech 2009;2:206-10.

7. Haider SG. Cell biology of leydig cells in the testis. Int Rev Cytol 2004;233:181-241.

8. Erb C. The Laboratory Rat. $2^{\text {nd }}$ ed. London: Elsevier Academic Press; 2006. p. 818-42.

9. Delbe G, Levacher C, Habert R. Estrogen effects on fetal and neonatal testicular development. Reproduction 2006;132:527-38.

10. Craig ZR, Wang W, Flaws J. Endocrine-disrupting chemicals in ovarian function: Effects on steroidogenesis, metabolism, and nuclear receptor signaling. Reproduction 2011;142:633-46.

11. Patisaul HB, Whitten PL, Naz RK. Endocrine Disruptor Effects on Male and Female Reproductive Systems. USA: CRC Press; 2005. p. 135-74.

12. Bucar F, Preedy VR. Isoflavones Chemistry, Analysis, Function and Effects. UK: RSC Publishing; 2013. p. 14-26.

13. Kim SH, Park MJ. Effects of phytoestrogen on sexual development. Korean J Pediatr 2012;55:265-71.

14. Retana-MarquezS,HernandezH,FloresJA,Munoz-GutierrezM,DuarteG. Vielma J, et al. Effect of phytoestrogens on mammalian reproductive physiology. Trop Subtrop Agroecosyst 2012;15 Suppl 1:129-45.

15. Svechnikov K, Izzo G, Landreh L, Weisser J, Söder O. Endocrine disruptors and leydig cell function. J Biomed Biotechnol 2010; 112:1-10.

16. Adachi T, Ono Y, Koh KB, Takashima K, Tainaka H, Matsuno Y, et al. Long-term alteration of gene expression without morphological change in testis after neonatal exposure to genistein in mice: Toxicogenomic analysis using cDNA microarray. Food Chem Toxicol 2004;42:445-52.

17. Lofamia EA, Ramos GB, Mamon MC, Salido FM, Su GA, de Vera MP. Isoflavone maternal-supplementation during periconception period: Influence on the reproductive organs of the first generation (F1) murine weanling-stage offspring. Asian Pac J Rep 2014;3:268-74.

18. Sherrill JD, Sparks M, Dennis J, Mansour M, Kemppainen BW, Bartol FF, et al. Developmental exposures of male rats to soy isoflavones impact leydig cell differentiation. Biol Reprod 2010;83:488-501.

19. Musameh NI, Zin SR, Kassim NM. Effect of genistein on male sprague dawley rats reproductive development. Biomed Res 2014;25:391.

20. Setchell KD, Brown NM, Desai PB, Nechimias LZ, Wolfe B, Jakate AS, et al. Bioavailability, disposition, and dose-response effects of soy isoflavones when consumed by healthy women at physiologically typical dietary intakes. J Nutr 2003;133:1027-35.

21. Pilšáková L, Riečanský I, Jagla F. The physiological actions of isoflavone phytoestrogens. Physiol Res 2010;59:651-64.

22. Yin D, Zhu Y, Liu L, Xu H, Huang J, Li Y, et al. [Potential detrimental effect of soy isoflavones on testis sertoli cells]. Zhong Nan Da Xue Xue Bao Yi Xue Ban 2014;39:598-604.
23. Sharpe RM, McKinnell C, Kivlin C, Fisher JS. Proliferation and functional maturation of sertoli cells, and their relevance to disorders of testis function in adulthood proliferation and functional maturation of sertoli cells, and their relevance to disorders of testis function in adulthood. Reproduction 2003;125:769-84.

24. Meena R, Supriya C, Pratap Reddy K, Sreenivasula Reddy P. Altered spermatogenesis, steroidogenesis and suppressed fertility in adult male rats exposed to genistein, a non-steroidal phytoestrogen during embryonic development. Food Chem Toxicol 2017;99:70-7.

25. O'Hara L, Smith LB. Androgen receptor roles in spermatogenesis and infertility. Best Pract Res Clin Endocrinol Metab 2015;29:595-605.

26. Qi-En Y, Oatley JM. Sertoli Cell Biology. $2^{\text {nd }}$ ed. Amsterdam: Elsevier; 2015. p. 81-98

27. Heffner LJ, Schust DJ. At a Glance Reproduction System $2^{\text {nd }}$ ed. Jakarta: Erlangga; 2008

28. Katarzyna P, Irena BB, Mariola M, Izabela G, Iwona N, Monika Z, et al. Changes in male reproductive system and mineral metabolism induce by soy isoflavones administered to rats from prenatal life until sexual maturity. Nutrition 2011;27:372-79.

29. Wu X, Wan S, Lee MM. Key factor in the regulation of fetal and postnatal leydig cell development. J Cell Physiol 2007;213:429-33.

30. Vladimir A, Ivana M, Jasmina Z, Marija M, Verica M. Membrane steroid-receptors-mediated action of isoflavones: Tip of the ice berg. J Membrane Biol 2015;248:1-6.

31. Zhang LD, Li HC, Chong T, Gao M, Yin J, Fu DL, et al. Prepubertal exposure to genistein alleviates di-(2-ethylhexyl) phthalate induced testicular oxidative stress in adult rats. Biomed Res Int 2014;2014:598630.

32. Zhu Y, Xu H, Li M. Xiaoming H, Yun L. Daidzein impairs leydig cell testosterone production and sertoli cell function in neonatal mouse testes: An in vitro study. Mol Med Rep 2016;14:5325-33.

33. Raheem I, Bamagous G, Omran G. Antiulcerogenic effect of genistein against indomethacin-induced gastric ulcer in rats. Asian J Pharm Clin Res 2016;9:58-63.

34. Basu P, Sunny S, Maier C. Estrogenic and antiestrogenic activities of commercial dietary supplements containing herbal ingredients and isoflavones. Int J Pharm Pharm Sci 2016;8:307-12.

35. Dongare S, Rajendran S, Senthilkumari S, Gupta SK, Mathur R, Saxena $\mathrm{R}$, et al. Genistein alleviates high glucose induced toxicity and angiogenesis in cultured human RPE cells. Int J Pharm Pharm Sci 2015;7:294-98.

36. Pankova S. Tsvetkova D. Role of phytoestrogens in preventing of osteoporosis. Int J Curr Pharm Res 2015;7:1-6.

37. Faqi AS, Johnson WD, Morrissey RL, McCormick DL. Reproductive toxicity assessment of chronic dietary exposure to soy isoflavones in male rats. Reprod Toxicol 2004;18:605-11. 